\title{
Geomorphological evolution of badlands based on the dynamics of palaeo-channels and their implications
}

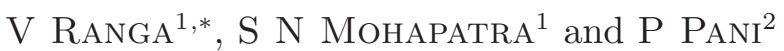 \\ ${ }^{1}$ Centre of Remote Sensing 83 GIS, School of Studies in Earth Science, Jiwaji University, Gwalior 474 011, India. \\ ${ }^{2}$ Centre for the Study of Regional Development, Jawaharlal Nehru University, New Delhi 110 067, India. \\ ${ }^{*}$ Corresponding author.e-mail: vikram.ranga85@gmail.com
}

The badlands along the lower Chambal valley represent the worst case of water erosion in India. These badlands are believed to have developed due to neo-tectonic activities and, probably, strengthening of southwest monsoon in late Pleistocene-Holocene. Due to neo-tectonic activities, the Chambal River has undergone many changes before reaching to its present planform. This study reports palaeo-channels on the Chambal River's right flank along its lower reaches. Salient features of the palaeo-channels and their relation to present spatial pattern of badlands are studied. These palaeo-channels have significantly influenced the development of badlands along the lower Chambal River and have given them distinct and conspicuous spatial patterns. In the light of the evidences, a modified schematic geomorphic evolution of badlands development is also proposed starting from a pre-incision scenario till the present day situation. A major modification in the proposed model is the multi-channel planform of the Chambal River before its incision.

\section{Introduction}

The formation of Himalaya Foreland Basin (HFB) leads to one of the most extensive alluvial plains in the world, i.e., Indo-Gangetic plains (Gibling et al. 2005), where, Ganga Plains represent the fore-deep (DeCelles and Giles 1996) part of the HFB system (Goswami and Mishra 2014). The southern margin of foreland basin is marked by a regional gentle fore-bulge (DeCelles 2011) in the form of Bundelkhand-Vindhyan Plateau (Singh 1996), while the northern margin is marked by the Shiwalik Hills. From north to south, the Ganga Plain can be subdivided into three geomorphic units: (1) Piedmont Zone (PZ), (2) Central Alluvial Plain (CAP), and (3) Marginal Alluvial Plain (MAP) (Singh 1996; Agarwal et al. 2002; Goswami and Mishra 2014), where, the MAP is enclosed by the Yamuna River and the Indian craton. Marginal Alluvial Plains are incised with the most severe intricate network of gullies, thus forming badlands (also known as ravines; figure 1) along the Chambal, the Betwa, the Yamuna rivers and their tributaries. Various evidences of neo-tectonic activities were recorded in the MAP. In fact, one of the most striking evidences of neo-tectonic activities is considered to be the incision of rivers and presence of badlands along them (Ahmad 1968; Sharma 1968; Mishra and Vishwakarma 1999; Agarwal et al. 2002). Mishra and Vishwakarma (1999) observed that alluvium tract of western MAP has experienced up-warping and down-warping wherein the Chambal River follows an anti-formal up-warp. Agarwal et al. (2002) observed tilted beds in the sedimentary layers, open fractures in the gullied areas along the Chambal and the Yamuna rivers. They, further proposed that Indian lithosphere behaved rigidly in the process of thrust loading in the orogen which led to formation of a set of conjugate faults near the peripheral bulge. Badlands

Keywords. Lower Chambal valley; palaeo-channels; geomorphologic evolution; badlands. 


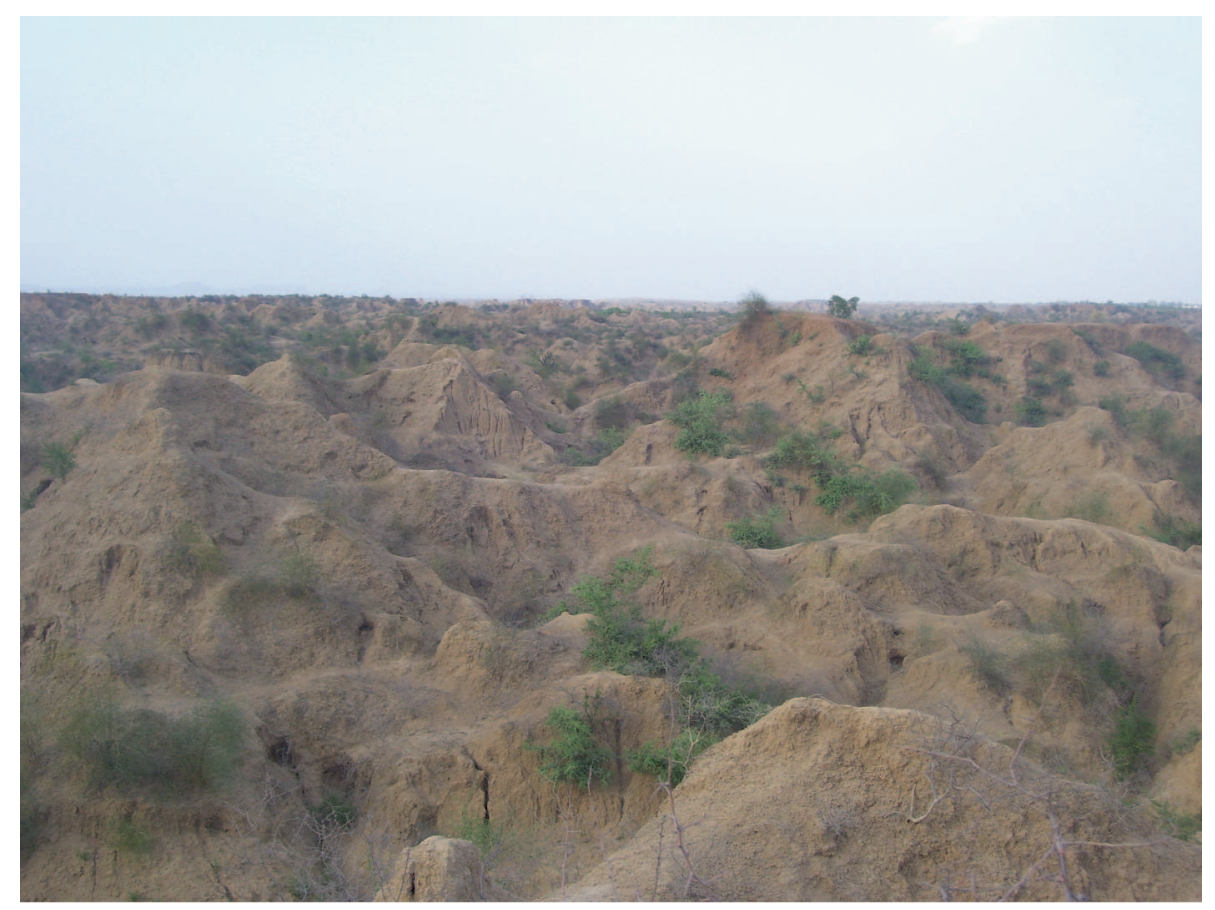

Figure 1. A typical scenario of intricate network of ravines in the lower Chambal valley.

presents the most spectacular scenery in the otherwise flat topography of deposited sediments in the lower Chambal valley, covering an area of ca. 4800 $\mathrm{km}^{2}$ (Sharma 1979). Along with the up-warping of the area, intensification of SW monsoon in the late Pleistocene-Holocene is also considered a possible reason for badlands formation (Tandon et al. 2006; Joshi 2014). However, the timing of badlands formation is not well constrained in the area but Gibling et al. (2005), after dating a gully fill in the Kalpi region, found that the youngest gully fill sediments are ca. $35 \mathrm{ka}( \pm 4 \mathrm{ka})$ old. Since these sediments are actually gully fills, gullies and badlands must have formed prior to that period (Tandon et al. 2006).

Mishra and Vishwakarma (1999), while studying morphotectonics along the lower reaches of the Chambal River, observed a $74 \mathrm{~km}$ long palaeochannel on the left flank of the Chambal River (a part of which is shown in figure 2). They further opined that the palaeo-channel was a tributary to the Chambal River and it has dried up before the incision of the latter. During the satellite interpretations, many similar toned dark linear/curvilinear features were observed running parallel to the lower reaches of the Chambal River, on its right flank. Interestingly, these features seem broken links and appeared to come from and diminish in to the badlands. Therefore, to they seem to present a strong link to badlands. Unlike the identified palaeochannel (by Mishra and Vishwakarma 1999), these features are straighter, interconnected and devoid of any apparent meandering. To the best of our knowl- edge, these features are not revealed so far in literature except in the Survey of India topographic sheets where these are marked as local drains. Therefore, in this study, first, their salient features along with their implications to spatial patterns of badlands are studied, while in the second part, a conceptual geomorphic evolution model is proposed.

\section{Regional setting and study area}

The Chambal River originates from the Vindhyan Range (Sharma 1979; Jain et al. 2007) and flows through the Malwa Plateau where Vindhyans are overlaid by the Deccan Traps (Narula et al. 2000). It runs a total length of $960 \mathrm{~km}$ (Jain et al. 2007), where its catchment area is divided into three parts, i.e., Upper Chambal Valley (UCV), Middle Chambal Valley (MCV) and Lower Chambal Valley (LCV) (Sharma 1979). A total basin area of the Chambal River is ca. $143,219 \mathrm{~km}^{2}$ (Jain et al. 2007) with a discharge of $387 \mathrm{~m}^{3} / \mathrm{s}$ and $22 \mathrm{M}$ tons/year of sediment load, measured at Dholpur station (Bawa et al. 2014). The discharge peaks in the monsoon season lasts for 3-4 months from mid-end of June till September. The average annual rainfall is ca. $800 \mathrm{~mm}$ (Ranga et al. 2015), more than $85 \%$ of which is received in the monsoon season (Tandon et al. 2006). The UCV and MCV are covered mainly with the rocky terrain; only the lower reaches flows on the alluvium, deposited by the Chambal River itself. The major part of the Chambal River, in the LCV, flows in parallel to Great Boundary Fault (GBF) and Chambal Jamnagar Lineament (CJL) 


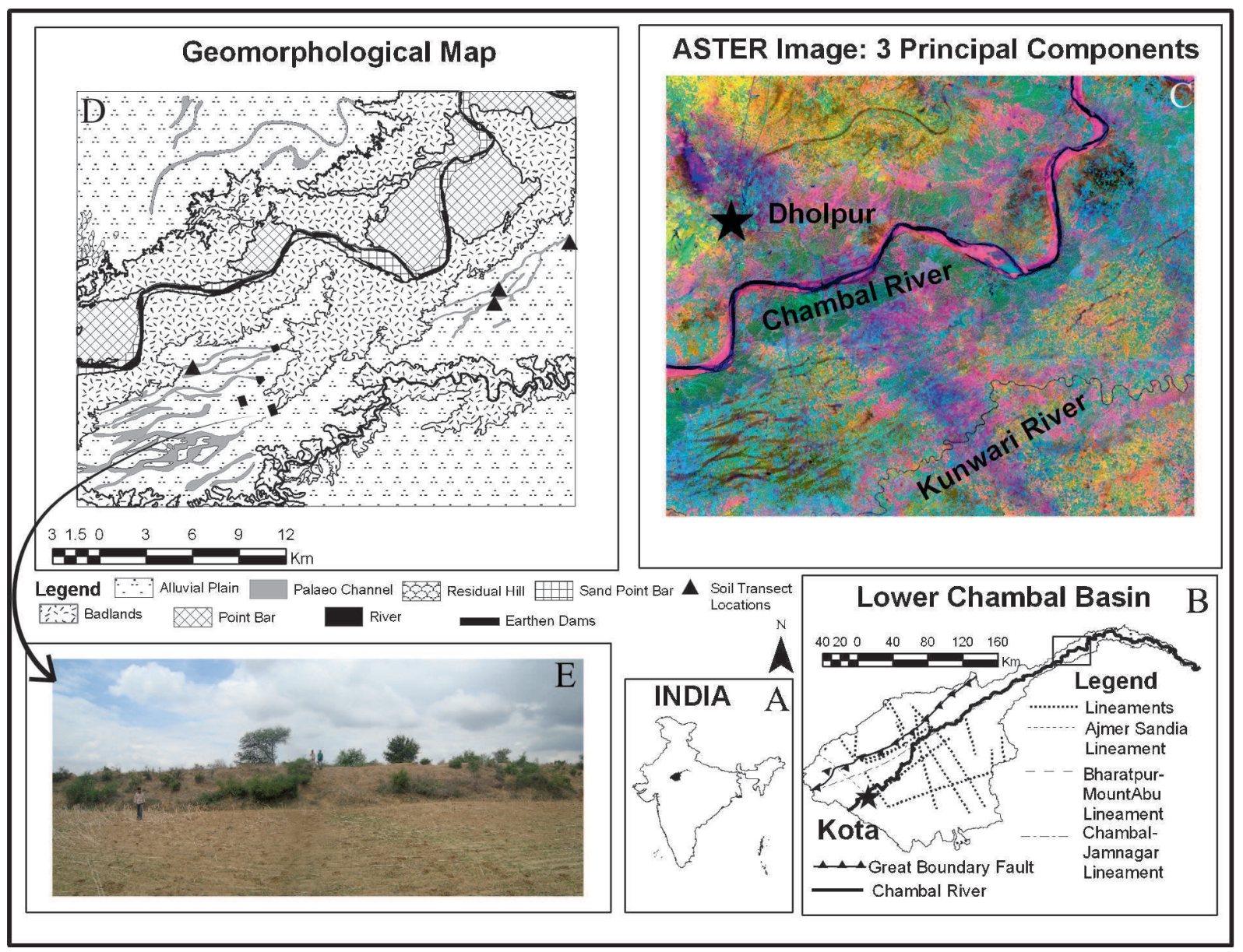

Figure 2. (a) Location of the lower Chambal valley in India; (b) structural control on the lower Chambal valley; rectangular box represents location of (c and d); (c) paleo-channels on the enhanced, with principal component analysis, ASTER image; (d) geomorphological details of the same extent as in (c) on the northern side of the Chambal River, palaeo-channel of Chambal is identified in Mishra and Vishwakarma (1999); and (e) panoramic field photograph of an earthen dam near village Tilonda (note person as scale).

(until Pinahat; see figure 3). GBF is a fault which runs along the boundary of Vindhyan basin (figure 2b) and extends for more than $400 \mathrm{~km}$ (Srivastava and Sahay 2003). CJL is a $900-\mathrm{km}$ long set of fracture systems and parallel faults which extends from Little Rann of Kutch/Jamnagar to Dholpur (Ramasamy 2005). GBF and CJL have SW-NE orientation and thus control the flow direction of the Chambal River in the LCV. A nick point is reported around Pinahat along longitudinal profile of the Chambal River by Mishra and Vishwakarma (1999); from this point (figure 3) onwards, the river changes its flow direction from SW-NE to NWSE. The average gradient of the Chambal River is $0.21 \mathrm{~m} / \mathrm{km}$ in LCV (Jain et al. 2007). Climate of the region can be classified as warm temperate $(\mathrm{C})$ steppe (S) with hot summers (a) i.e., Csa according to Köppen-Geiger updated classification (Kottek et al. 2006).

Badlands, in the LCV, incised the former active floodplains (which now are inactive) and formed a narrow valley. Steep scarps form the boundary between badlands and the adjacent inactive flood plains. At many places, levelling activities on such scarps were recorded, therefore, on such areas boundary becomes vague and land use becomes transitory (Ranga et al. 2015). The active flood plain is restricted to the narrow incised valley, marked by point bars on the concave curves of meanders (figure $2 \mathrm{~d}$ ), which are formed by meander cut-off and lateral migration of the river.

The palaeo-channels are all observed in the inactive floodplains which are now used for cultivation purpose. However, the paleo-channels exist all along the lower reaches of the Chambal River but, for a detailed study, a small part of LCV was taken (figure 2b, c and d). This part lies, almost, in the middle of LCV and is representative of the conditions of badlands in it.

\section{Datasets and methodology}

The datasets used in this study are from different sources, i.e., (1) Remotely sensed data, ancillary 




Figure 3. Location of the lower Chambal valley on the Chambal basin with geological details of lower Chambal basin with its major tributaries (source: Geological Survey of India and Survey of India).

data, (2) soil analysis, and (3) field verifications. The first section includes mainly satellite images from different sensors and published maps and data from various Govt. agencies. The latter sections include field verification of former section including soil surveys, feature identifications, field observations, etc.

\subsection{Remotely sensed data and ancillary data}

On-desk interpretation was carried out on a number of satellite images from different sensors including Landsat mosaics (spatial resolution = $30 \mathrm{~m}$ ) (http://earthexplorer.usgs.gov/) from Thematic Mapper sensor, images from LISS-III sensor ( spatial resolution $=23.5 \mathrm{~m}$ ) from Indian remote sensing satellites, Advanced Spaceborne Thermal Emission and Reflection Radiometer (ASTER) ( spatial resolution $=15 \mathrm{~m})$, GeoEye image (spatial resolution $=0.5 \mathrm{~m}$ ), images from CORONA missions (Galiatsatos 2004) (spatial resolution $=1.8 \mathrm{~m}$ (Sohn et al. 2004)) from the cold-war period (for more details on GeoEye \& CORONA image, see Ranga et al. 2015) and Shuttle Radar Topographic Mission (SRTM) digital elevation model (spatial resolution $=90 \mathrm{~m}$ ).

Additional information such as names of the villages in the study area, location of earthen dams, etc., was mapped from the Survey of India (SOI) topographic sheets $($ scale $=1: 50,000)$. Geological details were mapped from the geological maps (scale $=1: 2,000,000$ ) of the states of Madhya Pradesh and Rajasthan (available at: http://www. portal.gsi.gov.in) published by Geological Survey of India (GSI). The structural details were mapped from the GSI's seismo-tectonic atlas (Narula et al. 2000) $($ scale $=1: 1,000,000)$. The ancillary data was geo-referenced and projected to UTM projection with WGS84 as datum. This projection system is common with the satellite images used in this study. Geomorphological details were mapped from satellite images coupled with SOI topographic sheets and were later verified on field.

Satellite images and other ancillary data were used for visual purposes such as identification, marking, etc., there was no areal estimation made with pixel based analysis. In most of the analyses, information was extracted by digitization. Therefore re-sampling of the raster data to a common spatial resolution was unnecessary. Specifically, images from TM were used to make mosaic and extract palaeo-channels as line features. Higher resolution satellite images, i.e., GeoEye and CORONA images had limited coverage (a few hundred $\mathrm{km}^{2}$ ), therefore mosaics of TM images were used to extract palaeo-courses of the whole LCV. 
Catchment of the Chambal River was calculated from SRTM DEM. GeoEye image was taken to field in a laptop and with the help of a Garmin e-trex vista GPS device, it was used for navigation and identification of features. Images from CORONA mission was used to check the existence of the palaeo-channels, thereby ruling out human induced origin of the palaeo-channels. Different satellite images were used to maximize visual discrimination of palaeo-channels from their surroundings. For instance, an enhanced ASTER (with principal component analysis) image gave best visual discrimination and was used for geomorphological mapping for the study area (figure $2 \mathrm{c}$ and $\mathrm{d}$ ).

\subsection{Field verifications and soil analysis}

Field verifications were carried out in the months of June-July 2011. During field verification, physical properties, such as colour, width and extent, of palaeo-channels were documented. Field visits, also validated the on-desk interpretations of satellite image and other ancillary data. Additionally, four transects, across the palaeo-channels at four different locations (figure 2d), were made to study difference in soil texture. Soil samples were collected from top surface after removing ploughing layer $(\sim 20 \mathrm{~cm})$ from palaeo-channels as well as from the surrounding areas. A total of nine samples from palaeo-channels and 10 samples from the surrounding areas were taken. For soil texture determination, soil samples were mixed with dispersing agent and distilled water; the mixture was shaken overnight for better dispersion of soil particles. Silt and clay were separated by pipette using Stoke's law, while sand was separated by wet sieving. USDA soil triangle was used for calculating the soil texture and displaying of results.

\section{Results and discussion}

Following the chronology of the objectives, this section is subdivided into two parts: in the first part, salient features of the palaeo-channels and their relation to present pattern of badlands is studied. In the second subsection, a systematic conceptual geomorphic evolution of badlands along the LCV has been proposed.

\subsection{Salient features of palaeo-channels and their relation with the present spatial patterns of badlands}

A total of 113 palaeo-channels could be mapped from satellite images; they were also, conspicuously, discernible on the field due to their darker tone than their surroundings (figure 4a). The palaeochannels are not continuous but broken into fragments which seem to come and diminish into the badlands (figure 2c and d). Despite their broken nature, inter-connection can readily be seen. In most of the instances, encounter of palaeo-channels with badlands are marked with the earthen dams (figure $2 \mathrm{~d}$ and e). Beyond the dams, active channels leading palaeo-channels to the present course of the Chambal River could be traced. The palaeochannels were consistently seen in all the satellite images ranging from the oldest available satellite data, i.e., CORONA images from 1971 to the latest images from Landsat (1984-2003) and GeoEye-1 (2010) satellites. The palaeo-channels are normally ca. 200-300 m wide except at some places where more than one seems to have aggregated. Palaeochannels are readily discernable from a bit west of Sabalgarh town of Morena District in Madhya Pradesh state (figure 3).

The soil texture of palaeo-channels is quite different from that of its surrounding areas. At palaeochannels, soil has rather smaller particles, i.e., silt and clay, while in its surrounding areas, soil has comparatively larger amount of sand particles. This can be attributed to the reason that due to desiccation of flow, gradual decrease in stream energy was sufficient only to carry smaller soil particle and hence the observed soil texture.

However, during the field visit, in the month of June (peak summer), no water accumulation was observed either in the palaeo-channels or behind the earthen dams but water accumulations could, well be observed from satellite images from end-of-monsoon season, i.e., in the months of September-October. Water accumulations were not only observed at the terminus of palaeochannels (behind the earthen dams) but often, also along the palaeo-channels where people have created small ponds (locally known as 'Pokhar') by soil quarrying. In one such pond, remnants of a snail shells were observed (figure 4c). Presence of molluscan shells indicates water stagnation on palaeo-channel long enough to give molluscs enough time to grow and develop. Furthermore, these kinds of ponds act as a local sink which tend to alter original flow directions along the palaeo-channels.

Majority of the palaeo-channels have SW-NE orientation (figure 5a) which resembles the flow direction of the Chambal River. After Pinahat, flow direction of the Chambal River changes (figure 3) and so does for the palaeo-channels (figure 5a). Palaeo-channels seem to be favouring badland encroachment. For example, near village Gurja-ka-pura in Sabalgarh subdistrict of state Madhya Pradesh, badlands which seemed to be advancing southwards, suddenly took almost a $90^{\circ}$ 


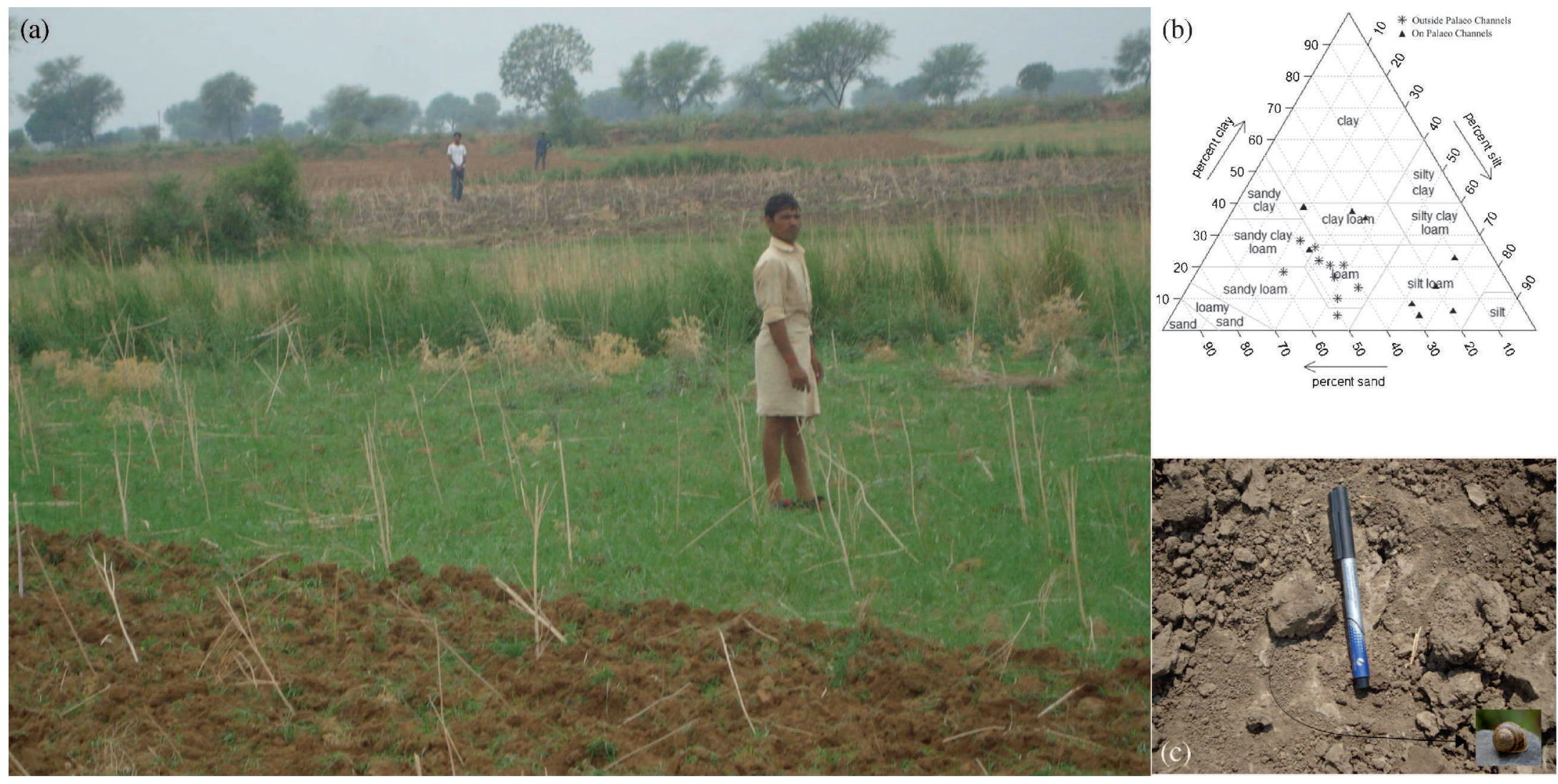

Figure 4. (a) Notice the clear contrast in soil colour, where middle person (in white shirt) standing, to the soils where other two persons are standing. The soil along the palaeo-channel is much darker than the surrounding soil. (b) Soil texture triangle (USDA) of soil from palaeo-channels and from adjacent to it. (c) Field photograph showing presence of a snail shell in a soil clump from a palaeo-channel. 




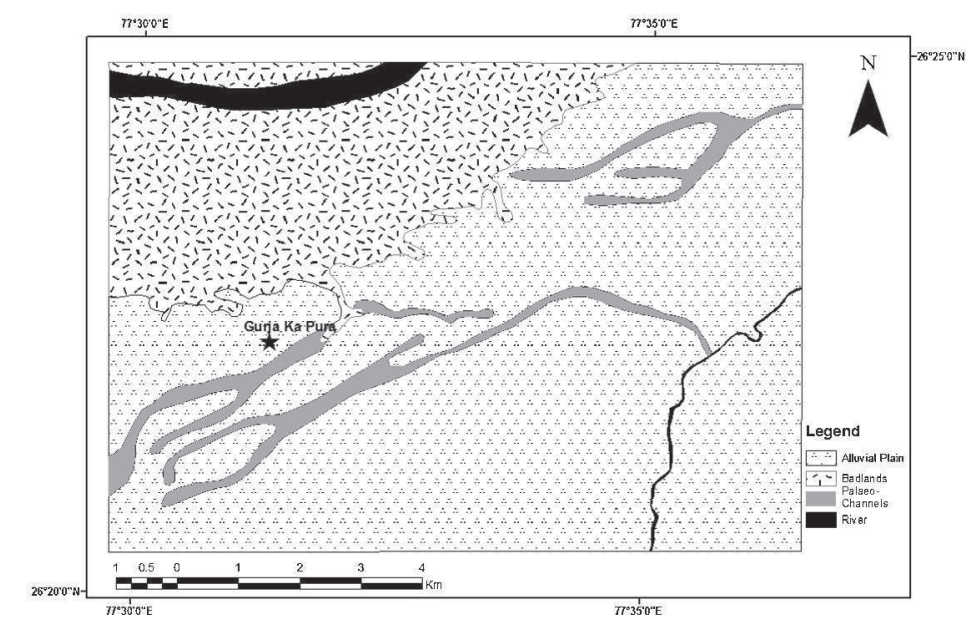

(b)

Figure 5. (a) Rose diagram of the palaeo-channel direction. (b) Badland encroachment turned almost $90^{\circ}$ on encounter with a palaeo-channel.

turn and started developing along a palaeo-channel (figure 5b). However, there are many such cases which could be observed along the LCV. One of the cases, where a t-shape badland encroachment formed (figure $6 \mathrm{~b}$ ), is the most prominent. From point $\mathrm{B}$ onwards (figure $6 \mathrm{~b}$ ), palaeo-channel can be tracked until its confluence with the Kunwari River (figure 6a). On its way to confluence with the Kunwari River, the palaeo-channel is active with a meandering channel while at other places, a mere dark tone is left. The fact that inter-connected palaeo-channel is intercepted, which otherwise is a complete network with an active channel, points towards a complex and inter-connected network of channels. After encroachment by the badlands, flow of the intercepted channel has changed towards the Chambal River. Following the elevation gradient, flow from point A should go to B but due to badland encroachment, flow direction from both points ( $\mathrm{A}$ and $\mathrm{B}$ ) were diverted towards the Chambal River. Between point $\mathrm{A}$ and $\mathrm{O}$, neither a dark tone nor a channel form exists but presence of an earthen dam between them points towards an extension of the latter to the former. This fact further indicates an inter-connected network. Further, lack of dark tone or channel feature can be attributed to land use, i.e., cultivation in the area.

A credible explanation, as shown in figure 7, can be described by a schematic diagram. Due to the homogenous nature of the alluvial deposit, erosion features should have equal opportunity to develop. However, if badlands are encountered with any palaeo-channels, direction of badland encroachment changes to SW-NE. It may be argued that palaeo-channels, with local depression along the channel, provide good environment for headward erosion which consequently abets formation of new gullies. Due to that, on encounter between badlands encroachment and palaeo-channels, headward erosion is favoured by palaeo-channels than otherwise, thereby forming peculiar spatial patterns (such as two horn-like structures in the middle of figure $2 \mathrm{~d}$ or t-shape in figure $6 \mathrm{~b}$ ).

Close proximity of palaeo-channels to the incised valley of the Chambal River and their contribution to the spatial patterns of badlands, both are indicative of an inter-connection between the former and the latter. Considering the inter-connectivity, it may be argued that these were a part of a stable Chambal River system, before the latter's incision. Such an inter-connected system indicates towards a multi-channel planform of the river. Multi-channel rivers with stable floodplains are defined as anastomosing river by Makaske (2001). Nanson and Knighton (1996) considered anastomosing rivers as a type of anabranching river but Makaske (2001) argued that anabranches nowadays applied to channels which drain flood waters. Makaske (2001) further argued that anastomosing rivers are not climate specific and can be observed in various climatic zones including semi-arid which is the climatic zone of the study area. In this study, inter-connections between palaeo-channels are still preserved and conspicuous, which indicates stable floodplains separating them. Further, as observed by Makaske (2001) anastomosis of river channels is more likely to occur in lower reaches of an alluvial river system in a low stream gradient environment.

Remote sensing is an indispensable tool in studying dynamics of a river system. In the IndoGangetic plains where lateral movement of a river and avulsion are a common phenomenon, remote sensing has been used extensively to study the same (Jain and Sinha 2003; Rajawat et al. 2003 


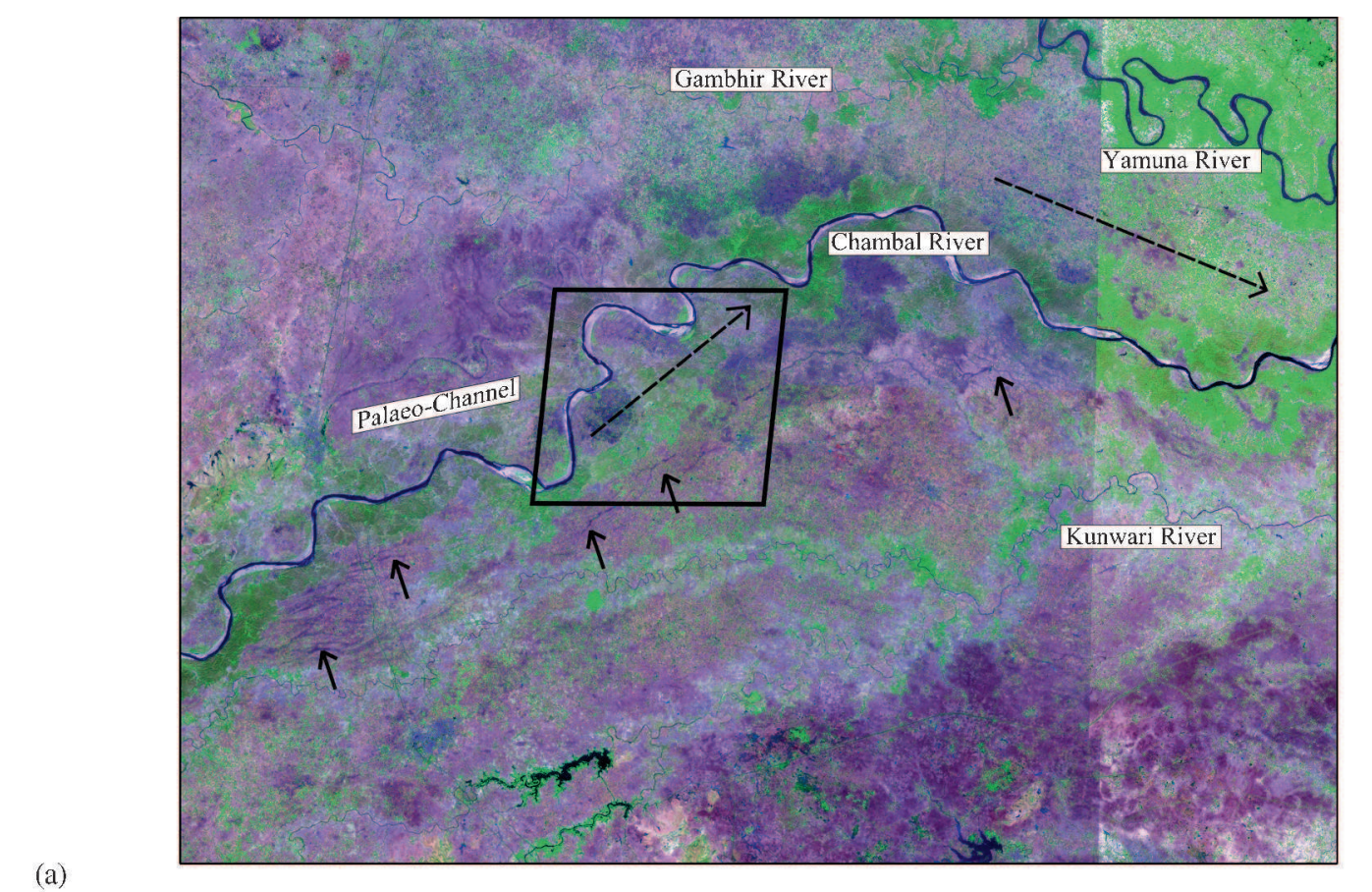

(a)

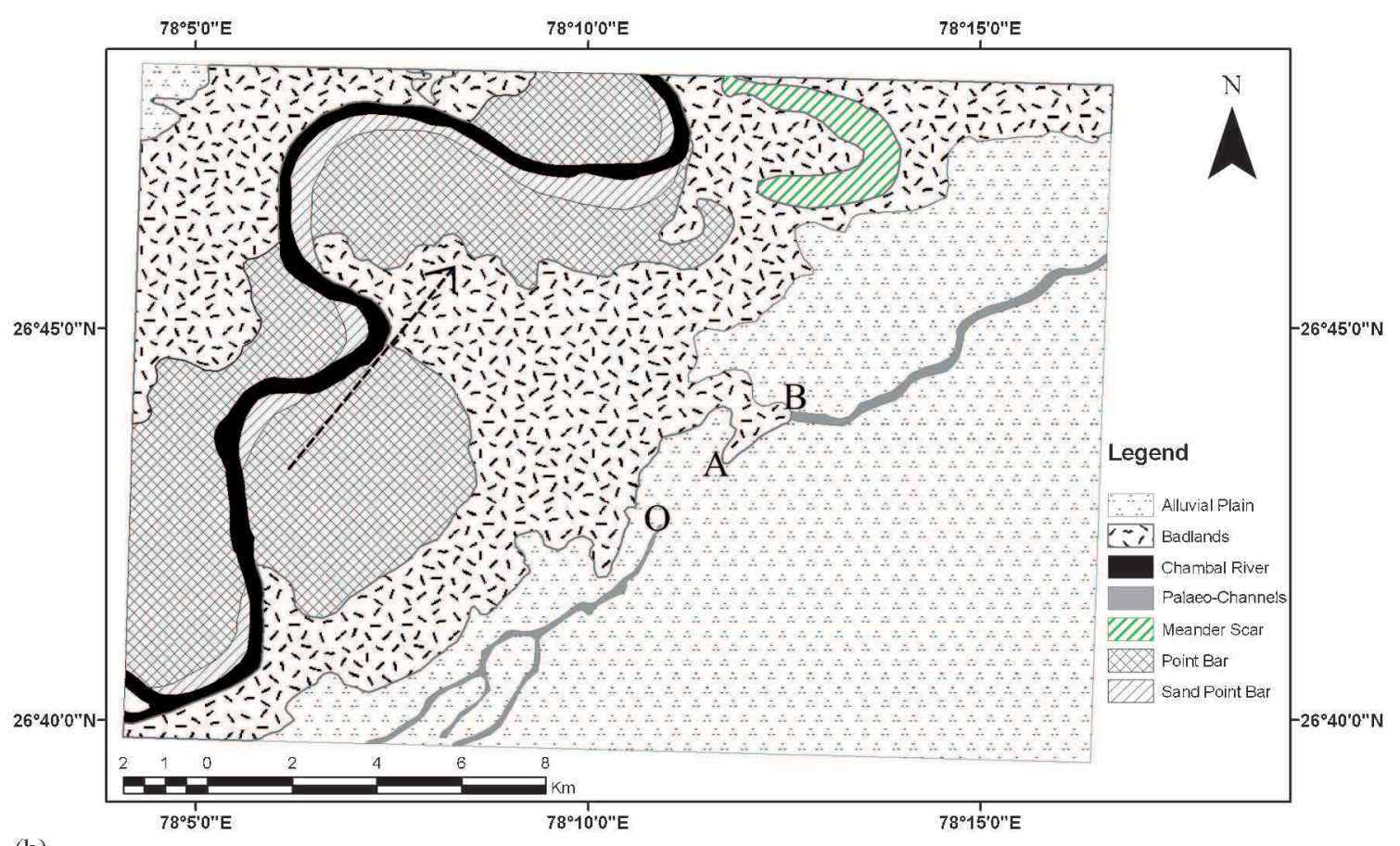

(b)

Figure 6. (a) A mosaic image from LISS-III sensor showing a portion of the LCV; solid line arrows indicate palaeochannels while dashed lines show direction of flow of the Chambal River, and (b) a detailed geomorphic map of the area marked by rectangle in (a); dashed line arrow indicates flow direction of the Chambal River and elevation gradient.

Mitra et al. 2005; Rathore et al. 2010). This study is different in the sense that much of the evidences are destroyed due to badland encroachment. Destruction of evidences, however, gave rise to peculiar spatial patterns to badland encroachment which helped in identifying them. Aging of sediments from the palaeo-channels would have been valuable but observations made in this study can form a hypothesis for a prospective study on the same. Dating of the sediments can also shed light on timing of Chambal's incision which then can be compared and contrasted with other river incisions in the area. 




Figure 7. A possible schematic explanation of processes shown in figures $5(\mathrm{~b})$ and $6(\mathrm{~b})$.

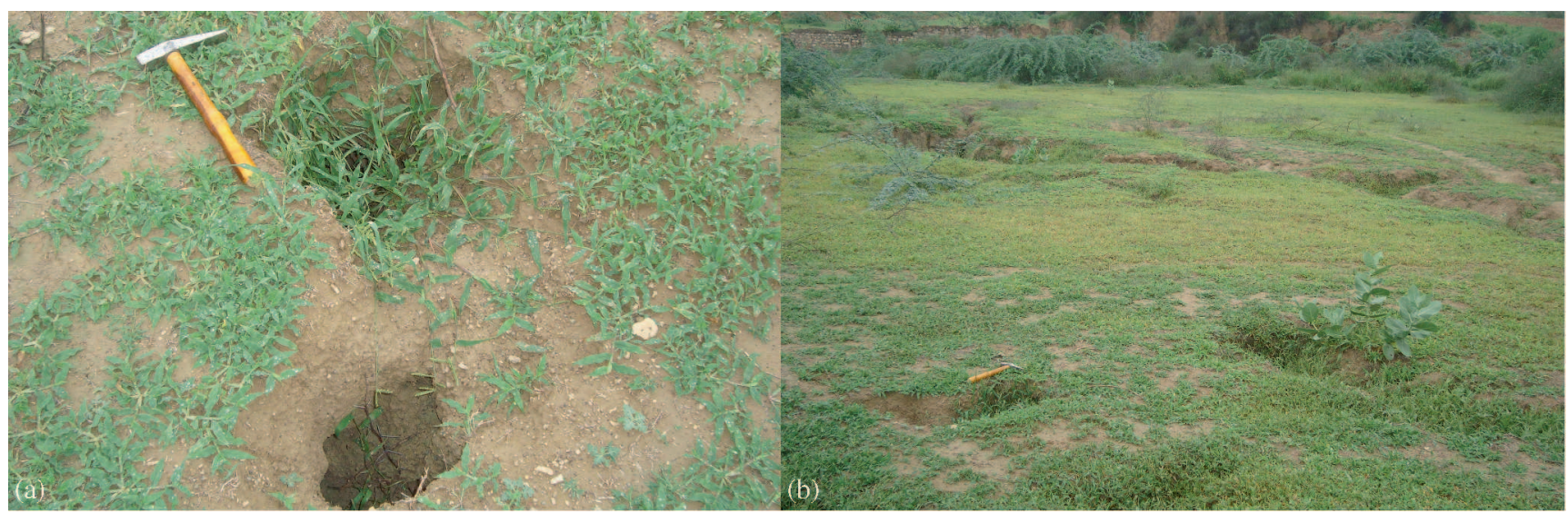

Figure 8. (a) Swallow holes and (b) two swallow holes adjacent to a gully. These features were observed in the badlands along the Kunwari River.

\subsection{Conceptual geomorphic evolution model}

A geomorphic model of evolution from the unincised Chambal River to the present day situation was originally given by Sharma (1968). This study, in the light of above observations, adds a concept of multi-channel planform of an un-incised Chambal River. Whole model can be explained in five stages as described below:

\subsubsection{Before uplift}

As noted by Agarwal et al. (2002), the last thrusting event in the Himalaya is believed to have caused the peripheral bulge (Singh and Bajpai 1989). They have, further considered last major thrusting event to be ca. 500-700 ka, when upper Siwalik sediments were thrusted and uplifted (Singh 1996). Consequently, peripheral bulge forced the Chambal 
River to incise (alluvial river incise in response to uplift, Ouchi 1985) and to find a new equilibrium.

Before the up-warp in the MAP, the Chambal River used to have a multi-channelled planform, as evidenced in the section above. The present location of the Chambal River can be attributed to the location of CJL; extension of CJL is until Dholpur, where it overlays on the present location of the Chambal River (figure 2b).

\subsubsection{Swallow hole and tunnelling (piping) stage (after uplift)}

The Chambal River has incised around 50-60 m to its original position after the uplift (Sharma 1979). Swallow holes, which are karstic features (Thornbury 1968), are considered pre-cursors of gullies and ravines in LCV by Sharma (1979). This consideration cannot be neglected due to two reasons: (1) such features were noticed during field visit (figure $8 \mathrm{a}$ and $\mathrm{b}$ ), and (2) higher concentration of $\mathrm{CaCO}_{3}$ was reported in soil of badlands than soil from croplands which points towards higher $\mathrm{CaCO}_{3}$ content in sub-surface layer (Ranga 2013). As shown in figure 8(a and b), swallow holes were developed and these are interconnected to each other. Over the course of time, these holes will connect to the nearby gully and thus will form a tunnel gully. Currently, there is hardly any data and analyses on why and how swallow holes or piping form in the LCV. Although, Verachtert et al. (2009) noted that lateral expansion and connection of pipes can be attributed to burrows by moles, the climatic conditions are completely different in two study areas. Nevertheless, internationally, piping has been accepted as a critically important soil erosion process which often results in gullies and rills (Faulkner 2006) and has been reported in a number of different climatic and soil conditions (Jones 1971; Faulkner 2006, 2008; Verachtert et al. 2009).

\subsubsection{Collapsing stage}

Pipes were connected to each other due to continued underground erosion. Connections of swallow holes formed tunnels where incision could be very deep. In this stage, tunnels were deep with thick roofs. Tremendous amount of soil were lost in this stage without having a surface reveal. When repeated erosion removes significant amount of soil from tunnels, the roof of tunnels becomes very weak. These weak roofs eventually collapse due to widening of gullies and thinning of roofs. This resulted in the formation of interconnected gullies (figure 9).
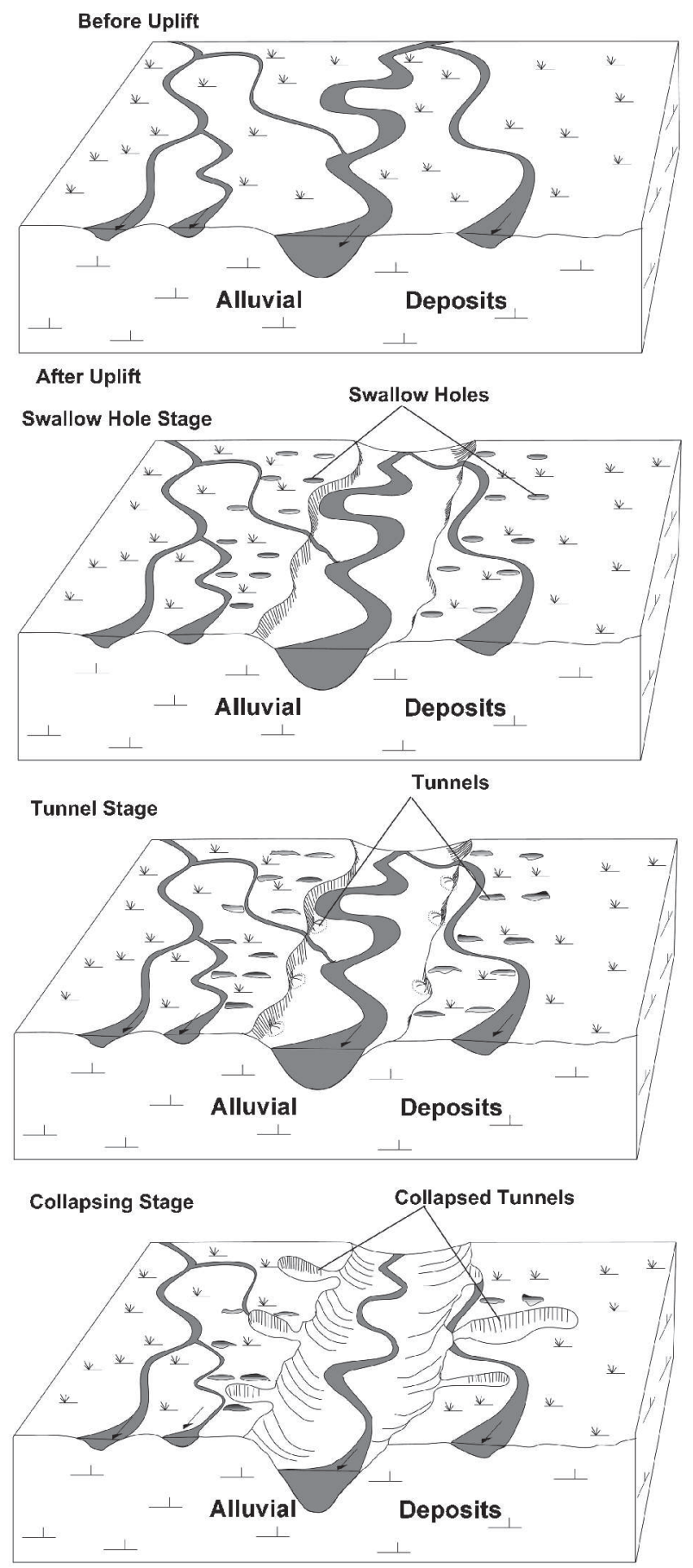

Recession Stage and Present Day Situation

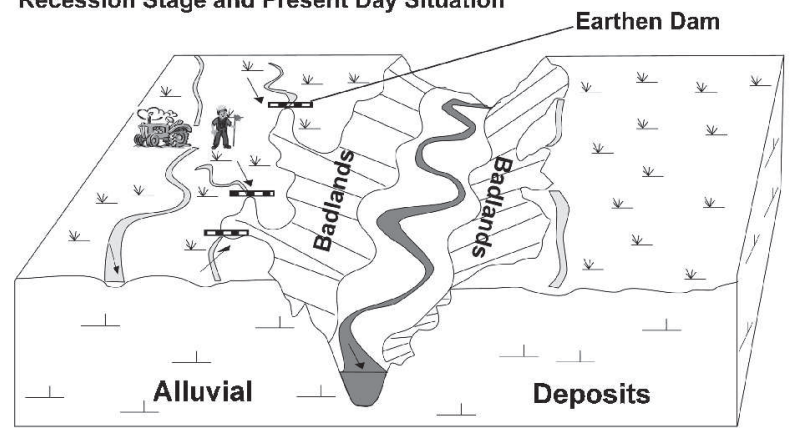

Figure 9. A schematic diagram of the evolution of badlands in the lower Chambal valley. 


\subsubsection{Recession stage and present day situation}

In this stage, the recession of already formed gullies continues by headward erosion. In the process of headward erosion, there can be number of processes involved including widening, branching of gullies, undercutting and plunge pools, etc. As shown by Ranga et al. (2015), vegetation activity varies over the year which may also influence erosion processes. During major part of the year, erosion activities are not so destructive but on the onset of monsoon huge soil losses could be seen. In the present situation, local people have made earthen check dams at the places where palaeochannels are meeting badlands. Consequently, badland extension by headward erosion ceased. At several places, local people made ponds along them to store water, altering direction of flow. In such a situation, there is further desiccation of flow in them. This low energy flow results in ephemeral stagnation of water which, possibly, gives paleo-channels their characteristic dark colour. Since, there is low water flowing through it, the outlines of streams started diminishing with farm practices. It has also been identified that these palaeo-channels after disappearing to badlands were continued by active channels. It cannot be neglected that formation of new gully heads or ascension of gullies from rills could have formed in parallel with formation of gullies from swallow holes. The idea of swallow holes, however, is still more attractive due to the present form of continuous gullies at the LCV. As discontinuous gullies could also have formed; their connectivity to other gullies can be explained by piping and tunnelling.

\section{Conclusion}

This study reports palaeo-channels observed on the right flank of the Chambal River along its lower reaches. The palaeo-channels are conspicuously visible on satellite images as well as on the field. The palaeo-channels are typically $200-300 \mathrm{~m}$ wide except where they seems either to have aggregated or a pond formed due to soil quarrying by local people. Headward erosion seems to be favoured by the palaeo-channels once they are encountered with gullies or ravines. Thus palaeo-channels played a significant role in shaping up the spatial patterns of badlands.

The palaeo-channels are interconnected to each other, to the Chambal and the Kunwari rivers. The proximity of the palaeo-channels and the incised rivers, points towards a multi-channel planform of the Chambal River before its incision. In the light of the evidences, a modified model of geomorphic evolution of badlands was proposed where multi-channel planform of the Chambal River is proposed against the single channel planform. Future researches should be focussed on more detailed analysis of the palaeo-channels such as cross-sectional elevation profile, soil profile study and most importantly constraining the age of the sediments.

\section{Acknowledgements}

The authors would like to thank Erasmus Mundus External Program, window 13 for financing the first author's stay at KU Leuven. Authors are grateful to Prof. Jean Poesen and Prof. Gert Verstraeten, KUL, Belgium for many useful insights and suggestions regarding analysis. They also like to acknowledge the help of GeoEye Foundation, who had provided the GeoEye image for this research. Authors are grateful to two anonymous reviewers for their very useful comments.

\section{References}

Agarwal K K, Singh I B, Sharma M, Sharma S and Rajagopalan G 2002 Extensional tectonic activity in the cratonward parts (peripheral bulge) of the Ganga Plain foreland basin, India; Int. J. Earth Sci. 91(5) 897-905, doi: 10.1007/s00531-002-0265-z.

Ahmad E 1968 Distribution and causes of gully erosion in India; In: 21st International Geographical Congress (Section IV), New Delhi.

Bawa N, Jain V, Shekhar S, Kumar N and Jyani V 2014 Controls on morphological variability and role of stream power distribution pattern, Yamuna River, western India; Geomorphology 227 60-72, doi: 10.1016/j.geomorph.2014.05.016.

DeCelles P G 2011 Foreland Basin Systems Revisited: Variations in Response to Tectonic Settings; In: Tectonics of Sedimentary Basins (eds) Busby C and Azor A, John Wiley \& Sons Ltd., pp. 405-426. http://onlinelibrary. wiley.com/doi/10.1002/9781444347166.ch20/summary.

DeCelles P G and Giles K A 1996 Foreland basin systems; Basin Research 8(2) 105-123, doi: 10.1046/j.1365-2117. 1996.01491.x.

Faulkner H 2006 Piping hazard on collapsible and dispersive soils in Europe; In: Soil Erosion in Europe (eds) Boardman J and Poesen J, John Wiley \& Sons Ltd., pp. 537-562, http://onlinelibrary.wiley.com/doi/10. 1002/0470859202.ch40/summary.

Faulkner H 2008 Connectivity as a crucial determinant of badland morphology and evolution; Geomorphology 100(1-2) 91-103, doi: 10.1016/j.geomorph.2007.04.039.

Galiatsatos N 2004 Assessment of the CORONA series of satellite imagery for landscape archaeology: A case study from the Orontes valley, Syria, http://etheses.dur.ac.uk/ $281 /$.

Gibling M R, Tandon S K, Sinha R and Jain M 2005 Discontinuity-bounded alluvial sequences of the southern Gangetic Plains, India: Aggradation and degradation in response to monsoonal strength; J. Sedim. Res. 75(3) 369-385, doi: 10.2110/jsr.2005.029.

Goswami P K and Mishra J K 2014 Morphotectonic evolution of the Piedmont Zone of the west Ganga Plain, India; Zeitschrift für Geomorphologie 58(1) 117-131, doi: 10.1127/0372-8854/2013/0114.

Jain V and Sinha R 2003 Hyperalvulsive-anabranching Baghmati river system, north Bihar plains, eastern India; Zietscrift fur geomorphologie 47(1) 101-116. 
Jain S K, Agarwal P K and Singh V P 2007 Hydrology and Water Resources of India; Springer.

Jones A 1971 Soil piping and stream channel initiation; Water Resour. Res. 7(3) 602-610, doi: 10.1029/WR007i $003 p 00602$.

Joshi V U 2014 The Chambal Badlands; In: Landscapes and Landforms of India (ed.) Kale V S (Dordrecht: Springer) 1st edn, pp. 143-149.

Kottek M, Grieser J, Beck C, Rudolf B and Rubel F 2006 World map of the Köppen-Geiger climate classification updated; Meteorologische Zeitschrift 15(3) 259-263, doi: 10.1127/0941-2948/2006/0130.

Makaske B 2001 Anastomosing rivers: A review of their classification, origin and sedimentary products; EarthSci. Rev. 53(3-4) 149-196, doi: 10.1016/S0012-8252(00) 00038-6.

Mishra M N and Vishwakarma L L 1999 Morphotectonics of the Chambal and the Yamuna valleys in the Western Marginal Gangetic Alluvial Plains; Geological Survey of India, http://www.portal.gsi.gov.in/pls/gsipub/ PKG_PTL_PORTAL_LINKS.pGetCaseStudyRegion?inp RegionId $=35$.

Mitra D, Tangri A K and Singh I B 2005 Channel avulsions of the Sarda river system, Ganga Plain; Int. J. Remote Sens. 26(5) 929-936, doi: 10.1080/0143116031000102458.

Nanson G C and Knighton A D 1996 Anabranching rivers: Their cuases, character and classification; Earth Surface Processes and Landforms 21 217-239.

Narula P L, Acharyya S K and Banerjee J 2000 Seismotectonic atlas of India and its environs; Geological Survey of India, Calcutta.

Ouchi S 1985 Response of alluvial rivers to slow active tectonic movement; Geol. Soc. Am. Bull. 96(4) 504-515, doi: 10.1130/0016-7606(1985)96<504:ROARTS > 2.0.CO;2.

Rajawat A S, Verma P K and Nayak S 2003 Reconstruction of palaeodrainage network in north-western India: Retrospect and prospects of remote sensing based studies; In: Proceedings Indian National Science Academy 69A $217-230$.

Ramasamy S M 2005 Remote Sensing in Geomorphology; New India Publishing.

Ranga V 2013 GIS based gully erosion mapping and modeling using multi-spectral spatial and non-spatial data in parts of Ambah and Morena Tehsils of Morena district, Madhya Pradesh Unpublished PhD thesis, Jiwaji University, Gwalior, India.
Ranga V, Van Rompaey A, Poesen J, Mohapatra S N and Pani P 2015 Semi-automatic delineation of badlands using contrast in vegetation activity: A case study in the lower Chambal valley, India; Geocarto Int., doi: 10.1080/10106049.2015.1004130.

Rathore V S, Nathawat M S and Champatiray P K 2010 Palaeochannel detection and aquifer performance assessment in Mendha River catchment, western India; $J$. Hydrol. 395 216-225, doi: 10.1016/j.jhydrol.2010.10.026.

Sharma H S 1968 Genesis of Ravines of the Lower Chambal Valley, India; In: 21st International Geographical Congress (Section IV), New Delhi.

Sharma H S 1979 The physiography of the Lower Chambal Valley and its agricultural development: A study in applied geomorphology; Concept.

Singh I B 1996 Geological evolution of Gangetic plain - an overview; Palaeontol. Soc. India 41 99-137.

Singh I B and Bajpai V N 1989 Significance of syndepositional tectonics in the facies development of Gangetic alluvium near Kanpur, Uttar Pradesh; J. Geol. Soc. India 36 61-66.

Sinha R and Tandon S K 2014 Indus-Ganga-Brahmaputra Plains: The alluvial landscape; In: Landscapes and Landforms of India (ed.) Kale V S (Dordrecht: Springer), 1st edn, pp. 53-63.

Sohn H-G, Kim G-H and Yom J-H 2004 Mathematical modelling of historical reconnaissance CORONA KH-4B Imagery; The Photogrammetric Record 19(105) 51-66, doi: 10.1046/j.0031-868X.2003.00257.x.

Srivastava D C and Sahay A 2003 Brittle tectonics and pore-fluid conditions in the evolution of the Great Boundary Fault around Chittaurgarh, northwestern India; J. Struct. Geol. 25(10) 1713-1733, doi: 10.1016/S0191-8141(03)00012-9.

Tandon S K, Gibling M, Sinha R, Singh V, Ghazanfari P and Dasgupta A et al. 2006 Alluvial valleys of the Gangetic Plains, India: Causes and timing of incision; In: Incised Valley (eds) Dalrymple R W, Leckie D A and Tillman R W, Tulsa 85 15-35.

Thornbury W D 1968 Principles of Geomorphology; Wiley \& Sons.

Verachtert E, Van Den Eeckhaut M, Poesen J and Deckers S 2009 Characteristics and distribution of soil piping erosion in loess-derived soils of Belgium; In: Congreso Internacional sobre Desertificacion. 